Article

\title{
Heritage Management: Analytical Study of Tourism Impacts on the Archaeological Site of Umm Qais-Jordan
}

\author{
Reem AlMasri and Abdelkader Ababneh *(D) \\ Department of Tourism \& Travel, Yarmouk University, Irbid 21163, Jordan; almasrireem55@yahoo.com \\ * Correspondence: abdelkader@yu.edu.jo
}

check for updates

Citation: AlMasri, R.; Ababneh, A. Heritage Management: Analytical Study of Tourism Impacts on the Archaeological Site of Umm Qais-Jordan. Heritage 2021, 4 , 2449-2469. https://doi.org/10.3390/ heritage 4030138

Academic Editor: Dmitry A. Ruban

Received: 24 August 2021

Accepted: 8 September 2021

Published: 15 September 2021

Publisher's Note: MDPI stays neutral with regard to jurisdictional claims in published maps and institutional affiliations.

Copyright: (C) 2021 by the authors. Licensee MDPI, Basel, Switzerland. This article is an open access article distributed under the terms and conditions of the Creative Commons Attribution (CC BY) license (https:/ / creativecommons.org/licenses/by/ $4.0 /)$.

\begin{abstract}
The archaeological site of Umm Qais is a popular tourist destination for both local and foreign tourists who come to appreciate the site's archaeological history, scenic landscape, and panoramic perspective. The site was the focus of tourism planning, which included the construction of amenities and infrastructure, the creation of tourist circuits, and archaeological management. This development was linked to a rise in visitor numbers as well as the provision of a high level of service, such as parking, tickets, kiosks, restaurants, and cafés, to welcome visitors. The purpose of this study was to examine the impacts of on-site tourist services and infrastructures, as well as those of visitors, and their geographical and temporal scope on the site. The study used a qualitative approach based on case study fieldwork as a research method to achieve this goal. Personal observation, interviews with site-related stakeholders, and a checklist were used to collect data during the fieldwork. Both tourism infrastructure and visitors were proven to have a detrimental influence on tourist attractions. The site's aesthetic pollution and structural deterioration were caused by tourism services and infrastructure. Graffiti, vandalism, and trash left by visitors exerted strong negative impacts. Furthermore, spatial and temporal negative impacts were determined by the patterns of seasonal movement of visitors and the location of infrastructure. Thus, most of the impacts were concentrated in a small portion of the site, among the western theater, the panoramic view, and the traditional Ottoman village. This research sheds light on these challenges and makes recommendations in the areas of heritage management, tourism, and visitor impact management that may be of interest to on-the-ground decision makers as well as academics.
\end{abstract}

Keywords: heritage management; tourism management; visitor and tourism negative impacts; impact extent; visitor management; Umm Qais; Jordan

\section{Introduction}

Umm Qais is one of Jordan's most important archaeological and heritage sites, located in the north of the country (Figure 1). The site is bordered in the north by the Yarmouk River, in the south by Wadi Al-Arab, in the east by Ar-Ramtha, and on the west by the Jordan Valley [1]. The archaeological site, which covers an area of approximately 14 fenced square $\mathrm{km}$, is divided into two sections: the classical era zone, which includes various archaeological monuments, and the Ottoman period zone, which includes conventional residential dwellings [2]. The site is normally open year-round. The hours of operation vary throughout the year (8:00 $h-19: 00 \mathrm{~h}$ in summer, 08:00 $\mathrm{h}-16: 00 \mathrm{~h}$ in winter). Based on the revised Law of Antiquity No. 21 for the year 2003 and the Tourism Law No. 20 for the year 1988, the Ministry of Tourism and its Department of Antiquities (Ministry of Tourism and Antiquities-MoTA) are the competent authorities for administrative and legislative problems relating to the site's archaeological and tourism activities. 


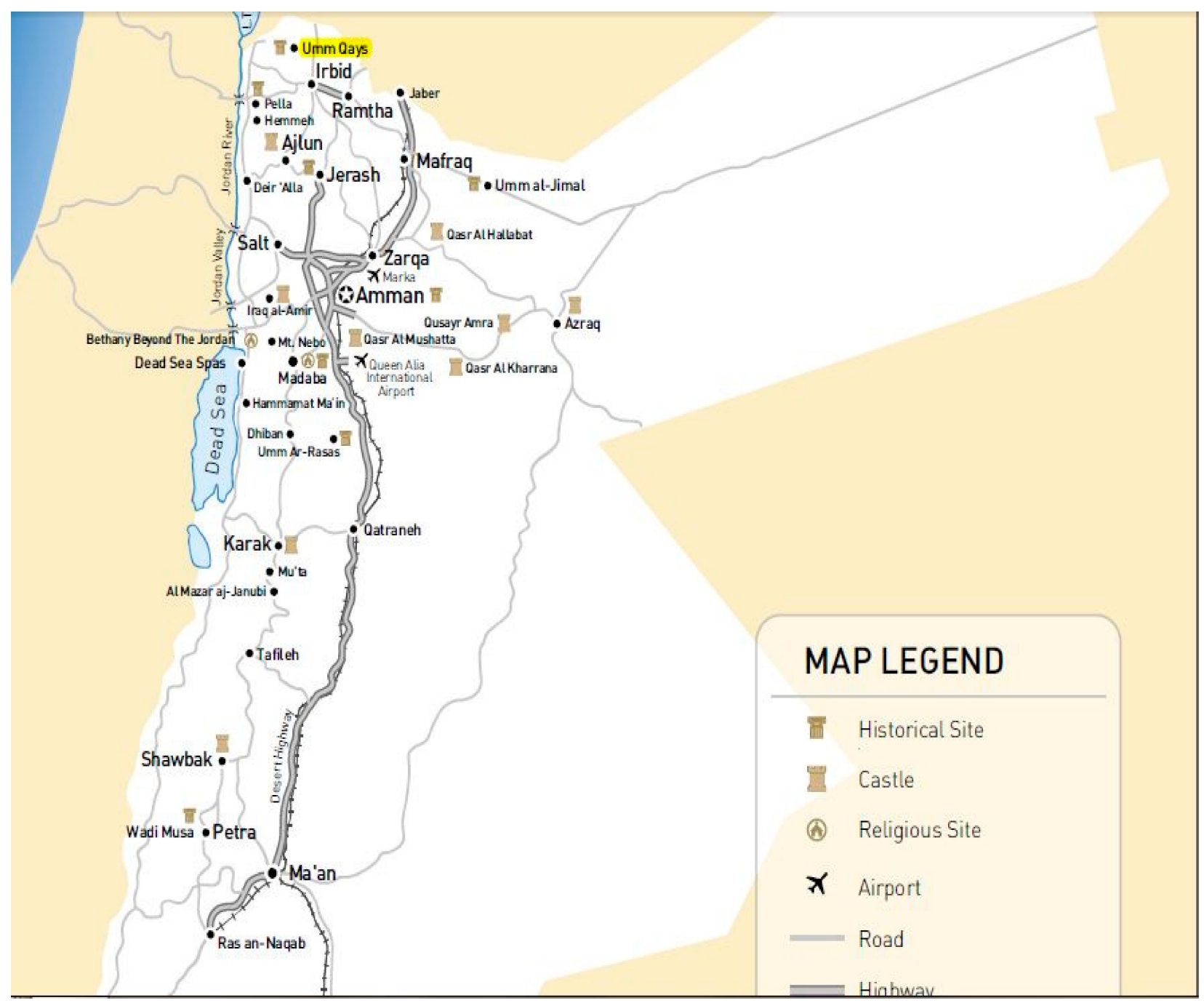

Figure 1. Map of Jordan with location of Umm Qais. Source: Modified by researchers based on an image from the Jordan Tourism Board.

The mid-1970s marked the start of the growth of the local tourism industry at the site. Tourist arrivals sparked the construction of tourism-related infrastructure. Every year, a huge number of national and international visitors travel to Umm Qais' archaeological site. Table 1 indicates tourist arrivals to the site. For example, in 2018 and 2019, the site received 146,656 and 78,518 visits, respectively [3]. Over recent years, a general pattern in tourism seasonal variations can be observed. The peak seasons for tourism arrivals in Jordan and Umm Qais are during March-April (spring season) and September-October (autumn season). Interestingly, however, Umm Qais exhibits a rise-and-fall pattern in tourist arrivals. Like other tourist sites in Jordan, Umm Qais is subject to fluctuations due to political stability in the region, the financial crisis, and the outbreak of the corona virus pandemic. Umm Qais usually ranks as the third or fourth most popular site among Jordanian tourist attractions. Over the years, local tourism has continuously generated employment in Umm Qais. Jobs range from administrative technical to seasonal excavation work. There are now about 300 jobs, but most are seasonal. 
Table 1. Monthly number of visitors to Umm Qais by nationality, 2018-2019, according to MOTA (2021) [3].

\begin{tabular}{ccccccc}
\hline & \multicolumn{2}{c}{$\mathbf{2 0 1 8}$} & & \multicolumn{2}{c}{$\mathbf{2 0 1 9}$} \\
\hline Month & Total & Jordanian & Foreign & Total & Jordanian & Foreign \\
\hline January & 1541 & 312 & 1229 & 3741 & 1689 & 2052 \\
\hline February & 3800 & 1726 & 2074 & 4561 & 1739 & 2822 \\
\hline March & 45,934 & 43,115 & 2819 & 9906 & 6714 & 3192 \\
\hline April & 58,509 & 52,873 & 5636 & 15,618 & 8984 & 6634 \\
\hline May & 5761 & 3040 & 2721 & 6134 & 2445 & 3689 \\
\hline June & 2550 & 887 & 1663 & 4438 & 1739 & 2699 \\
\hline July & 4469 & 2868 & 1601 & 5207 & 2565 & 2642 \\
\hline August & 6145 & 3709 & 2436 & 5847 & 2661 & 3186 \\
\hline September & 4726 & 1820 & 2906 & 6013 & 1571 & 4442 \\
\hline October & 5690 & 1218 & 4472 & 7533 & 1247 & 6286 \\
\hline November & 4476 & 845 & 3631 & 5837 & 959 & 4878 \\
\hline December & 3055 & 657 & 2398 & 3683 & 1107 & 2576 \\
\hline Total & 146,656 & 113,070 & 33,586 & 78,518 & 29,898 & 48,620 \\
\hline
\end{tabular}

Tourism activities and tourist habits, on the other hand, may have a detrimental impact on the site. The negative effects are thought to be linked to the expansion of services and tourist infrastructure, as well as the rise in visitor numbers, particularly during peak tourism seasons.

In practice, first observations of different management techniques might indicate a range of management difficulties. Despite the fact that local heritage and tourism authorities prioritize the preservation and development of historic resources, numerous heritage resources, monuments in Umm Qais, and valuable artifacts at the site are in jeopardy, suggesting the need for more effective management.

Many publications were produced in reference to the conservation of World Heritage sites [4], thus providing guidance for those involved in the care of heritage sites. Heritage management studies of the twentieth century focused on the legislative framework of heritage management, including protection guidelines and best practices within heritage sites, and many publications were produced in reference to the conservation of World Heritage Sites. As heritage management research advanced, heritage management scholars became more analytical, concentrating on topics like authenticity, management techniques, site values [5], heritage interpretation [6], visitor impacts [7], heritage tourism, tourism experience [4], and visitor management [8]. Although earlier heritage management studies have identified the phenomena of tourist impacts, little scholarly attention has been paid to tourism and visitor impacts inside historic heritage sites. In order to bring a greater understanding of tourism and its impacts, this study, underpinned by a heritage management background, draws on heritage tourism, visitor management, as well as the impacts of tourism. The majority of previous national studies either focused on specific ancient sites, such as Petra and Jerash, or examined the economic, socio-cultural, and environmental consequences of tourism; studies examining tourism concerns, visitor impacts, and degradation factors are desperately needed, particularly at the local level. For example, [9] investigated the provenance of white marbles sampled from monuments at the site of Umm Qais. Ref. [10] studied the impacts of heritage tourism on the site. Furthermore, [11] looked at the various effects of tourism growth on the site. Few studies have looked at the impact of tourism and visitor-induced impacts on archaeological sites in general, and the site of Umm Qais in particular. From the standpoint of heritage management, the various studies have not yet addressed the specific impacts and their spatial and temporal 
extent. As a result, tourism and visitor impact studies are essential for creating heritage management, tourist management, visitor management, and development plans that will ensure the preservation of sites, monuments, and their values for current and future generations. Academics from a variety of disciplines, including heritage management, heritage tourism development, heritage preservation, and visitor management, have worked to better understand tourism's influence on cultural sites. The purpose of this study is to look at the negative impacts of tourism and tourists on the site of Umm Qais. In addition, in order to decrease the danger of damage, this research will suggest management protection and visitor management techniques.

\section{Literature Review}

Heritage is undeniably a valuable touristic resource across the world. Heritage and tourism are sometimes viewed as two intertwined professions [12]. Heritage resources are one of the draw factors for heritage tourism [13]. Ref. [14] stated that heritage is one of the pull factors for heritage tourism; on the other hand, heritage may be seen as a machine that generates tourism excursions [15]. "Heritage is a rising tourism product providing tourists with experiences based on the (in) tangible remains of the past" [14]. The availability of diverse values associated with heritage resources and sites appears to have prompted both individuals and governments to seek out ways to transform these resources and sites into tourism attractions. Tourism transforms heritage sites into tourism products and portrays site images. It must be recognized that a successful heritage experience necessitates not just good tourism planning, but also good cultural heritage management. When there are good heritage management methods in place, the abuse created by tourism activities at heritage sites may be prevented. Heritage management is a complicated concept and an interdisciplinary area comprising many activities, such as site identification and evaluation, tourism development, site interpretation and protection, tourism impacts, and visitor management [16]. Heritage management practices, for example, serve as guidelines for heritage and tourism management. According to [17], heritage management involves the management of visitors to a prehistoric or historic place with the purpose of enhancing the visitors' appreciation and experience. The various operations, on the other hand, are designed to help heritage site managers conserve and protect their heritage assets. Heritage management is carried out in a variety of ways, including site monitoring and visitor management, in order to develop and manage visitor experiences. In a cultural heritage tourism venture, failure to embrace diverse heritage management practices can lead to different challenges [7].

Heritage is a delicate and endangered resource [18]. Heritage sites' physical and non-physical characteristics are subject to a variety of degradation causes [19]. Natural and human-based elements have been classified as degradation causes in several studies of heritage management and conservation. Climate change, floods, earthquakes, moisture, and erosion are examples of natural causes [20,21]. War, illicit commerce, illegal excavations [22], theft [23,24], conflict [25], urban expansion, and the tourism boom [7] are examples of human causes. Tourism impacts have increased as tourism and visitors have grown. The introduction of a new tourist activity or the expansion of an existing one at a historic site can have a variety of positive and negative consequences. The literature on tourism-induced impacts is divided into two categories: those that discuss positive benefits and those that detail negative ones. Positive impacts can be defined as cultural, economic, social, and environmental advantages. Employment and hard cash creation are regularly highlighted as positive outcomes in the literature. According to [26], tourism is Egypt's solution to unemployment. While tourist development and usage of cultural sites may be beneficial, tourism at heritage sites can also be a source of heritage damage. There are dissimilar types of tourism negative impacts as [22] put forward; tourism can have negative consequences, such as increased urbanization, pollution, migration of people, and trash. Palumbo looked at tourists' anarchist actions as a factor that damages monuments, facilities, and services. Visitors have a negative impact on heritage sites and the values associated 
with them [27]. Different case studies [28,29] demonstrate various aspects of tourist impacts. For example, the huge number of visitors to Beijing's Forbidden City has had a significant impact on the palace flooring and stepping-stones [30]. Over-tourism on Spanish beaches has also had an impact on many types of rock, coral reefs, and marine biodiversity [31]. According to [32], population development, urbanization, tourism movement growth, and land use change have all had an impact on the site of Jarash, resulting in visual pollution, flora deterioration, and destruction of many monuments. Ref. [32] went on to claim that the site's mismanagement was evidenced by stakeholder disputes, unfair distribution of tourist profits, and a degradation of the site's cultural image. Visitors are also a cause of deterioration at heritage sites, according to [33], owing to behaviors such as climbing and sitting on monuments, crowding, and souvenirism. Petra is subject to a number of impacts produced by the local population, visitors, and tourism development operations, according to [34]. Visitors and their related activities, according to [11], are responsible for a variety of hazards to cultural sites, including monument degradation owing to increasing humidity, climbing, and tourists treading on certain monuments. Tourism, according to [35], has a negative impact on the cultural significance and identity of places. To put it another way, visitor expansion and the facilities and amenities that come with it frequently lead to a loss of site value and authenticity.

The impact of tourism on heritage sites falls into three broad categories: environmental, economic, and social and cultural [36]. Depending on the case, degradation at heritage sites may be classified into three categories, including mechanical (wear, tear, and abrasion), physical-chemical (graffiti, waste, littering, and vandalism) and biological (pollution) [37]. Tourism impacts may also be categorized on the basis of spatial and temporal aspects [38]. Ref. [39] suggested that three variables may influence visitors' impacts on cultural sites:

Quantitative: Tourists use a small portion of the heritage site.

Qualitative: Tourism selects the key attractive monuments.

Spatial: Tourism is clustered in relatively small areas at various temporal bases.

The negative consequences have been linked to tourism development activities and visitor mobility; some studies, such as [40], believe that tourist effects are first and foremost a result of tourism development, which includes tourism services, facilities, and infrastructure (electricity, rest houses, parking, and roads). The impact of visitors is primarily determined by their quantity, time-space distribution, and length, as well as their conduct and activities. Impacts are also determined by features of visited sites such as fragility, size, environmental and cultural context. Visitors and their associated activities are very dynamic due to the wide range of visitors' lifestyles and characteristics (age, education, nationality, and length of stay).

In order to limit the negative impacts of tourism-related activities and their various consequences, such as waste, cigarette butts, and inscriptions, it is recommended to develop a visitor management system that includes both hard (regulation, fences, zoning, and flow management) and soft (management, protection, and legislation) measures [5,7,39]. To conclude this section, there are different studies about the site of Umm Qais. These studies have not yet completely investigated heritage management and tourism impacts on the site. The conducted studies are mainly focused on selected topics and issues, such as archaeology and provenance of marble [9], revival of cultural heritage [41], spatial assessment of urban growth in the cities of the Decapolis [42], and excavation reports. However, the issues surrounding the impact of tourism and visitors on the archaeological site of Umm Qais are very scarce.

\section{Materials and Methods}

Protecting a site's features and values is at the heart of heritage site management. The identification of degradation factors is crucial to protection. The heritage management planning process involves strategies and choices on a variety of issues, including tourism, tourist services and facilities, and negative consequences. The conservation of heritage sites can be harmed by poor or ineffective heritage and tourism management. According 
to heritage management practice, when turning heritage sites into tourist attractions, a variety of issues must be addressed, including degradation factors, their extent, and mitigation methods. This study aims to investigate the impacts of tourism and tourists on archaeological sites. The current study aims to investigate the negative impacts of tourism-related infrastructure and visitors' associated activities on the archaeological site of Umm Qais. The study looks to determine the extent of those impacts, and recommend heritage and tourism management practices to reduce tourism and visitor-induced negative impacts. To conduct this research, the researchers utilized a qualitative approach based on a case study. In fields including tourism, management, and anthropology, the case study is one of the oldest qualitative research techniques [43]. The archaeological site of Umm Qais was chosen as a case study for a number of reasons, including its importance as a tourist attraction in Jordan and its future development potential. The qualitative method was chosen because it gives a large amount of data for documenting human behavior and allows for a more in-depth investigation, leading to more reliable findings [44,45].

The triangulation technique was utilized in the fieldwork, which included observation, a checklist, and interviews. The researchers utilized non-participant observation since they are not involved in giving the data, but are involved in collecting it. The population of the study included international and local visitors (individuals, couples, and groups) in addition to infrastructure, services, and facilities, e.g., food and beverage services, business retailing, trash receptacles, and lights available at the site in order to develop on-site tourism. The researchers visited the site twice in December 2017 to get a sense of the present situation in terms of tourist impacts, visitor patterns, and the most frequently visited monuments. Following that, they kept track of visits during peak and off-peak seasons. However, observations were carried out from December 2017 to June 2020. Weekends and the peak of the season were the most popular times for fieldwork. As a result, the researchers were able to make more observations of the negative impacts. Visitors and their behaviors were observed from the beginning to the end of their visits, and approximately 3000 photographs were taken during the fieldwork. Actual fieldwork has increased the researchers' experience and understanding of this issue, which has been coupled with the conceptual framework from the literature study to aid them in adopting the relevant methods. The researchers created a checklist that covered things like the types of negative impacts associated with tourism and tourists, as well as their location. The list's parts were inspired by research that identified negative impacts; they were derived from [46-48]. The checklist was used to see whether there were any available impacts and where they might be found. The checklist was created to keep track of the many negative impacts that tourism and tourists have on the site. The researchers conducted seven semi-structured face-to-face interviews with key stakeholders familiar with the site and with Umm Qais' tourism activities and heritage, including the antiquities manager, a local tour guide, the tourism and visitor center manager, the museum curator, the ticketing office staff, the ticketing monitor, and a foreman (Table 2). The interviewees were chosen based on the belief that their contributions to the study's issue would be very useful. Interviews began on 16 October 2019, and ended on 22 October 2019. Each interview lasted an average of 30 minutes. The interviews took place in Arabic before being translated into English. They were recorded on a Samsung phone, and before each interview, the researchers gave a brief explanation of the project and the nature of the questions that were asked of the participants. The data was analyzed throughout time and classified into many categories based on the study's objectives. The items on the checklist were compared to the photos that had been taken. After the fieldwork was done, the researchers transcribed the audio recordings of the interviews. The data was meticulously organized and classified, and the interviews were completely conceptually examined. A few themes were used in the study's analytical phase. Finally, the data was analyzed in light of some of the literature supplied at the start of the research. 
Table 2. Information about interviewees.

\begin{tabular}{|c|c|c|c|}
\hline Item & Age & Nationality & Training Courses \\
\hline $\begin{array}{l}\text { Curator of the } \\
\text { museum } \\
\text { (interviewee } n^{\circ} 3 \text { ) }\end{array}$ & 51 & Jordanian & $\begin{array}{c}\text { Electronic marketing and promotion } \\
\text { Initiatives design } \\
\text { Training of trainers-Archaeology } \\
\text { Heritage learning and awareness of young people } \\
\text { Technology and archaeological documentation } \\
\text { Restoration }\end{array}$ \\
\hline $\begin{array}{c}\text { A foreman } \\
\text { (interviewee } n^{\circ} 5 \text { ) }\end{array}$ & 45 & Jordanian & $\begin{array}{c}\text { Stone carving } \\
\text { Preserving heritage and environment } \\
\text { Restoration }\end{array}$ \\
\hline $\begin{array}{l}\text { Manager of the site } \\
\text { (interviewee } n^{\circ} 1 \text { ) }\end{array}$ & 51 & Jordanian & $\begin{array}{l}\text { Managing archaeological sites } \\
\text { Senior management } \\
\text { Administrative development } \\
\text { Frisco restoration }\end{array}$ \\
\hline $\begin{array}{l}\text { Tourism manager and } \\
\text { manager of the } \\
\text { visitor center } \\
\text { (interviewee } \mathrm{n}^{\circ} 2 \text { ) }\end{array}$ & 46 & Jordanian & $\begin{array}{c}\text { Managing archaeological sites, } \\
\text { Initiative design } \\
\text { Development and management and manage } \\
\text { tourism sites } \\
\text { Communication skills, } \\
\text { Risk analysis } \\
\text { Bilad-Al sham } 1 \text { \& } 2 \text { to restore mosaics } \\
\text { Archaeology science } \\
\text { Leadership skills } \\
\text { Development of ecotourism in the middle } \\
\text { east countries } \\
\text { International Computer Driving License (ICDL) }\end{array}$ \\
\hline $\begin{array}{l}\text { A local tour guide } \\
\text { (interviewee } n^{\circ} 4 \text { ) }\end{array}$ & 49 & Jordanian & $\begin{array}{c}\text { Tourism marketing } \\
\text { Wilderness first aid } \\
\text { Value of biodiversity } \\
\text { Communication skills } \\
\text { Hotel management, } \\
\text { Tour guiding, } \\
\text { Ecotourism guiding, } \\
\text { Designing tourist trails using compass, GPS } \\
\text { and maps }\end{array}$ \\
\hline $\begin{array}{c}\text { Ticketing staff } \\
\text { (interviewee } \mathrm{n}^{\circ} 6 \text { ) }\end{array}$ & 55 & Jordanian & No training courses \\
\hline $\begin{array}{c}\text { Ticketing staff } \\
\text { (interviewee } \mathrm{n}^{\circ} 7 \text { ) }\end{array}$ & 34 & Jordanian & $\begin{array}{c}\text { English conversation, } \\
\text { Trainer of trainers } \\
\text { International Computer Driving License (ICDL) }\end{array}$ \\
\hline
\end{tabular}

\section{Results}

\subsection{Tourism Impacts}

The development of the site started in the 1960s and has continued to this day. As a consequence, the site now has extra facilities and services. Some of these facilities, such as restaurants and the tourism office, have reused old Ottoman Village houses to serve their new functions (non-adaptive reuse), whilst others, such as the main parking and the police station, have just recently been added. The introduction and growth of tourism amenities, services, and infrastructure has resulted in a number of different outcomes. As interviewee n 3 pointed out, "There is a trend to turn the site into a destination for tourism investment in order to boost the site's economic advantages. In fact, this will have a negative influence on the archaeological site's historical value and authenticity". Furthermore, these structures, as well as their associated activities and infrastructure, have negative consequences. According to interviewee n 2, "one of the most significant impacts of tourism is the spatial distribution of kiosks that result in visual pollution. While the 
Ministry of Tourism and Antiquities organized them in a designed zone, they increased the problem of pollution and resulted in a blatant attack on the environment".

According to observations, one of the most significant consequences of tourism on the archaeological site is the exploitation of ancient structures for tourist development objectives. Different effects, on the other hand, might be a direct outcome of these behaviors. For example, waste and energy use by the museum, the visitor center, the tourism police station, and the antiquity office may change the environment of the site and have negative impacts on the buildings themselves. These constructions have the potential to disturb the archaeological site and the historic area as long as these houses have been subject to change and renovations. Another factor that exacerbated the negative impacts was the fact that these projects necessitated the installation of infrastructure such as power, telecommunications, and septic services, as well as water and sanitation services. Furthermore, these infrastructures may cause the fundamental structure and archaeological deposits to deteriorate. It's worth mentioning that various sites, such as the museum, parking, visitor center, and restaurants have served as important centers for events involving their workers or tourists. The paving of several pathways and corridors connecting the homes of the Ottoman Village (Figure 2), which enabled the mobility and access of staff and tourist cars to the parking lot, as well as some of the heavy machinery distributed around the site, had unforeseen repercussions.

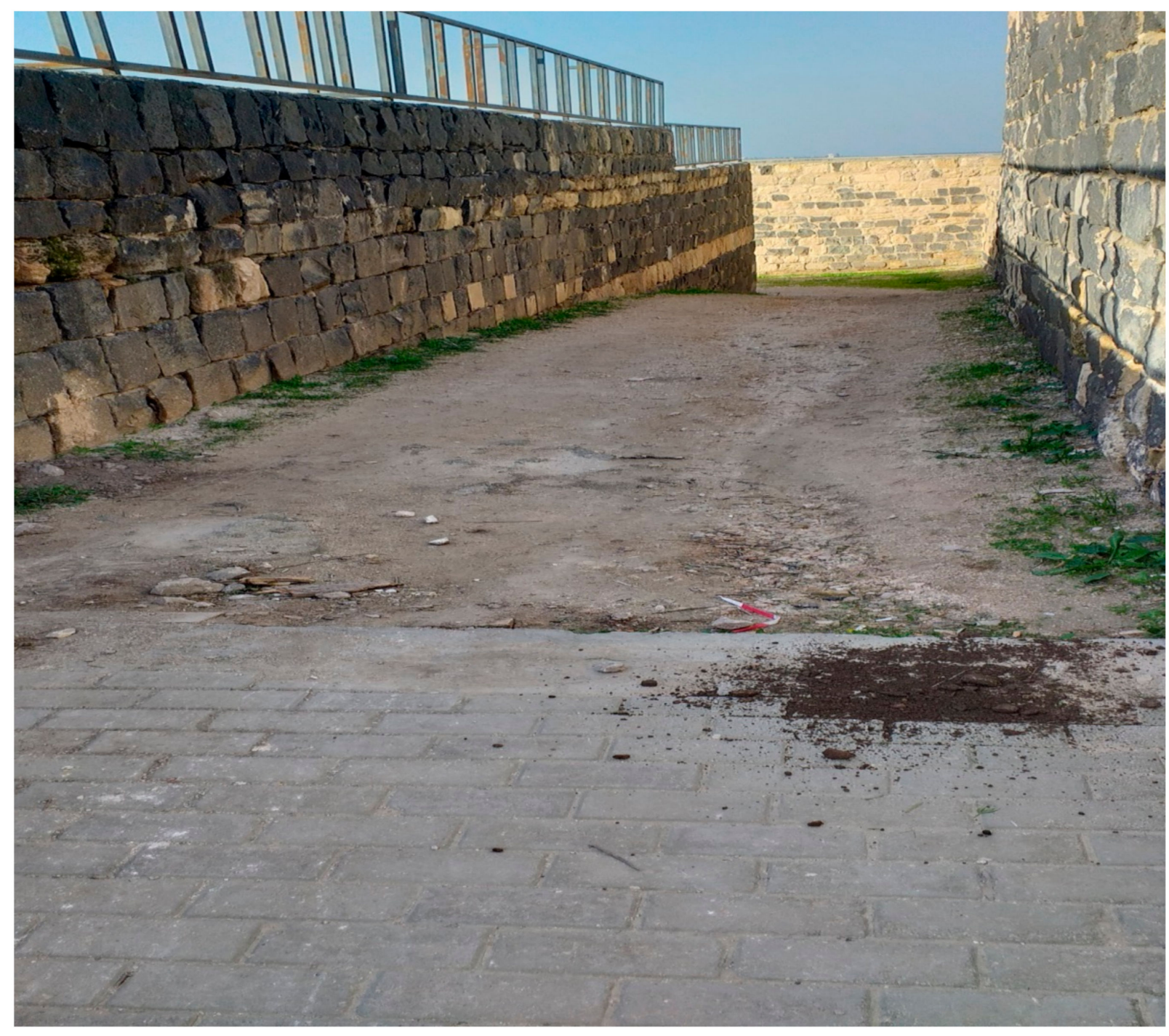

Figure 2. Pavement at the site. Source: Researchers. 
Conservation initiatives have a variety of negative impacts on the site, including the use of materials and procedures that might cause the monuments to be destroyed (Figure 3). An excavation campaign was undertaken in the region between the site's main street and the panoramic view during the study's fieldwork.

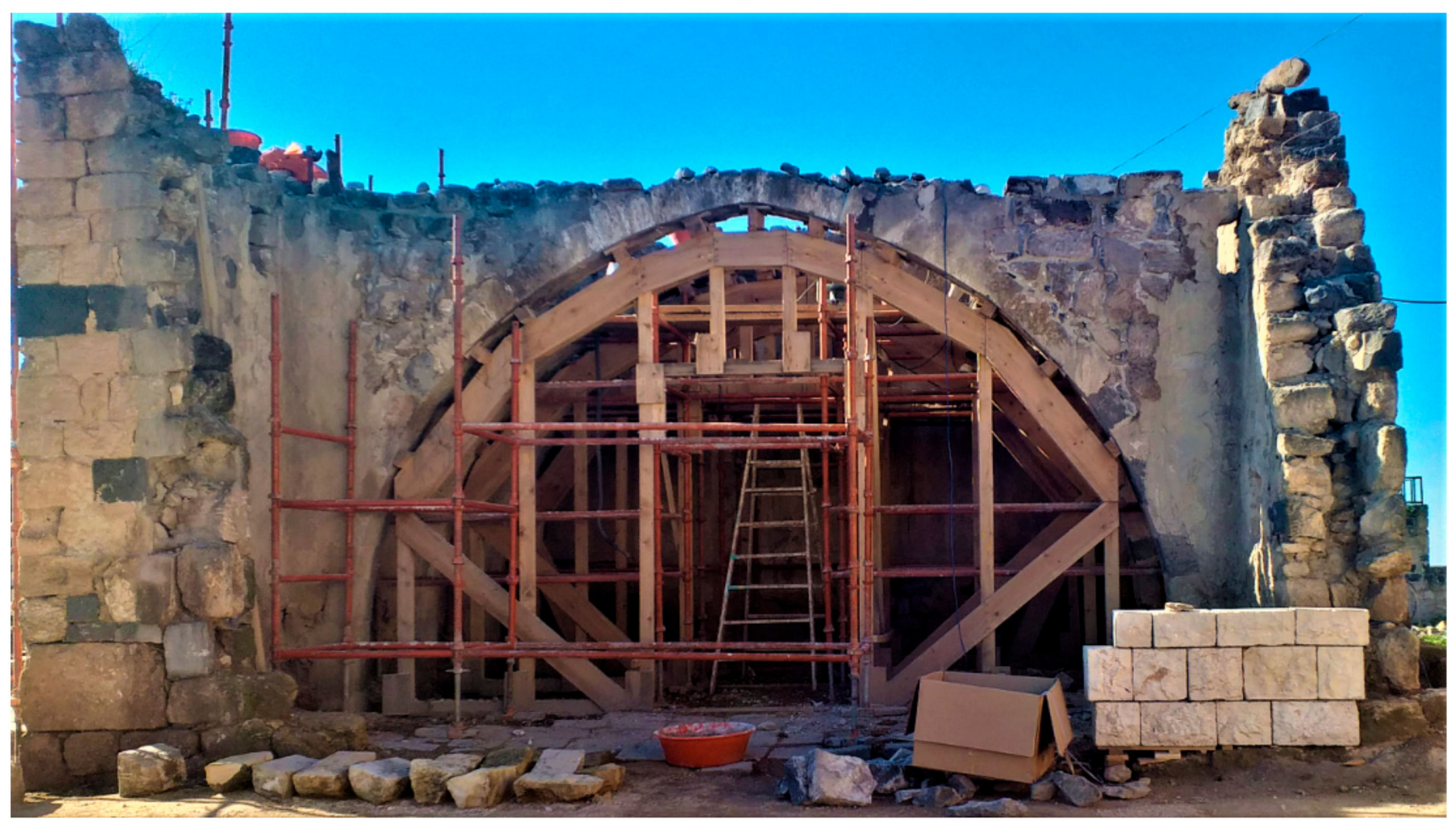

Figure 3. Conservation interventions at the Site. Source: Researchers.

The excavating process necessitated the employment of large gear such as cranes and bulldozers. Excavation workers have been caught wandering and lounging on antiquities, as well as pounding the floor of the Decumanus Maximus with their equipment. Furthermore, it was discovered that the excavation crew lacked the presence and supervision of a qualified conservator.

\subsection{Visitor Impacts}

During peak seasons, the site sees an increase in tourist traffic. Damage, degradation, and negative effects began to develop as the number of visitors increased. The findings of this study show that these consequences vary depending on where they occur. As a result, these effects have been organized into sections, starting with the most ubiquitous and ending with the least frequent.

\subsection{Littering}

During the fieldwork, plastic bags, coffee and tea cans, mugs, food and food wrappers, plates, metals, papers, cigarette butts, and bottles were noticed cluttering the site in various forms. Furthermore, animal excrement was commonly noticed throughout the spring season, which might detract from the site's attractiveness, increase pollution, and emit bad odor. Littering happens in different areas with varied concentrations based on the visited monuments, but more particularly at places where services are situated and frequented by people, according to the checklist (Figure 4).

The respondents agreed that various types of littering convey the sense and image of a dirty, unclean place, and that littering might be considered to have an impact on visitors' experiences. The interviewees alluded to littering in a variety of ways. For example, interviewee $\mathrm{n} 1$ stated that trash is the only negative impact of visitors, adding that "some 
tourists conduct excursions to the site and utilize the green spaces for picnics, and they leave the food behind them". "Throwing garbage is a direct assault on the site", said interviewee number 3.

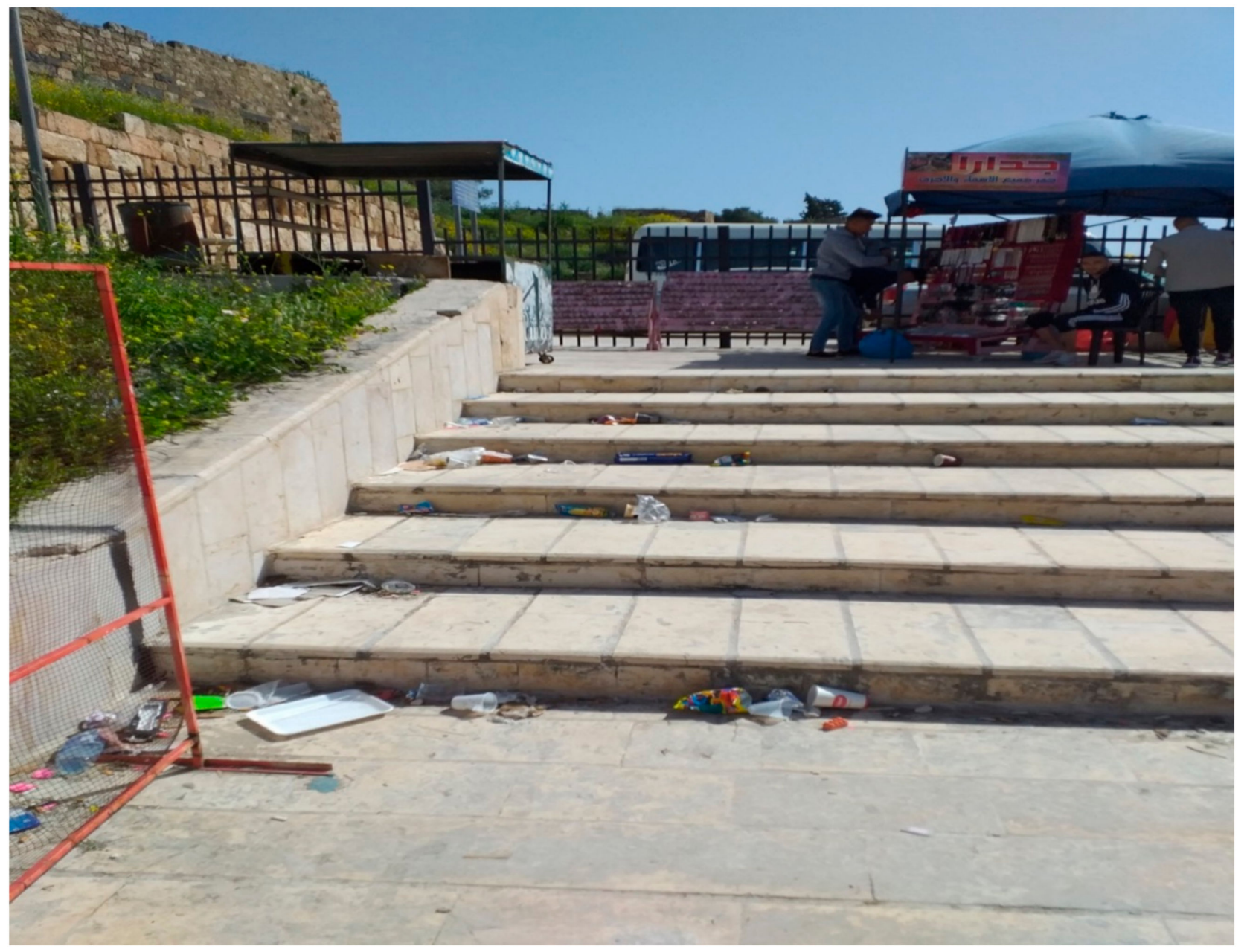

Figure 4. Littering at the site. Source: Researchers.

\subsection{Congestion, Traffic, and Overcrowding}

Various indicators, such as tourism development and growth, indicate that traffic will worsen at the site, resulting in a variety of negative outcomes, such as overcrowding at specific trails and monuments, which is a problem directly related to the issue of congestion, such as the main theatre, the panoramic view, and the parking area. When tourists arrive in the parking lot and begin their tours, this occurs. During the school trip season, the problem of overcrowding becomes much worse. One of the most common reasons of irritation during a visit to the site has been noted to be tourist congestion (Figure 5).

One of the biggest difficulties during the high tourist season, according to the interviewees, is traffic and congestion. The large number of visitors resulted in serious traffic issues around the site because the road outside is just one lane, and there were many tourists visiting neighboring tourist destinations such as Yarmouk Valley and Himmah. Some of them wanted to enter the site, others wanted to leave, which created a suffocating traffic crisis. As a result, traveling for 2 kilometers might require two hours to reach due to the abnormal traffic. It becomes "exceedingly difficult in the spring season", said interviewee number three. 


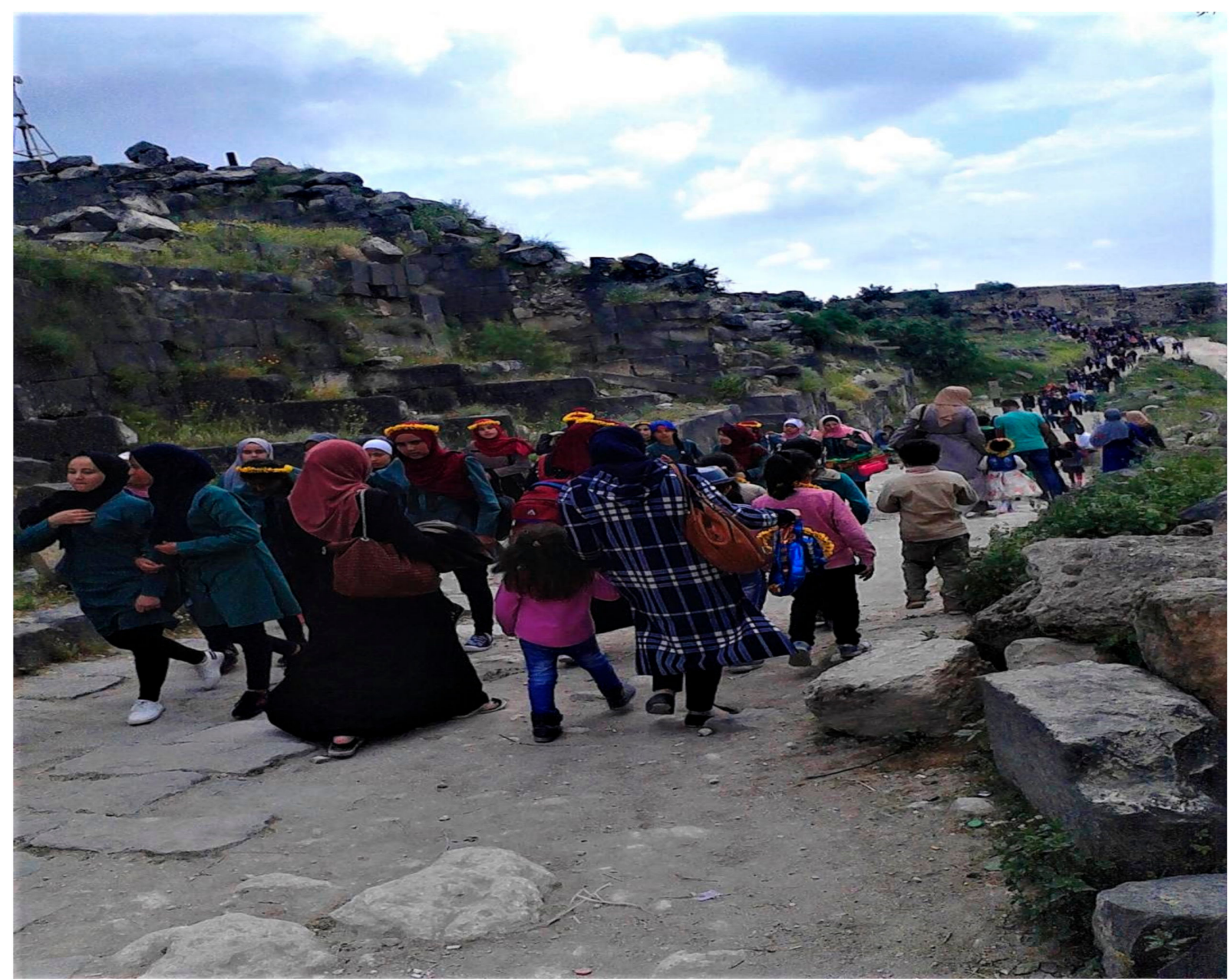

Figure 5. Overcrowding at the site. Source: Researchers.

\subsection{Vandalism}

Locals and visitors alike are bringing vandalism to Umm Qais. Different alarming cases of vandalism at the site were identified using the checklist; usually include degradation and elimination of infrastructure and services, such as garbage cans. The respondents expressed their unhappiness with some of the guests' disruptive activities in this respect. "A huge number of the lighting units, rubbish bins, signage, and sanitary units have been destroyed by youthful visitors who were meant to be aware of the value of the monuments", stated interviewee $\mathrm{n} 2$. Additionally, Graffiti in various spray colors was found on monuments, walls, signs, and columns, as well as some site embellishments. The majority of them include names, phone numbers, and dates of site views (Figure 6).

In addition, some individuals insist on touching the statue of the goddess Tychy, "interviewee $\mathrm{n} 4$ said, pointing out that "some people insist on touching the statue of the goddess Tychy"."Many school children snap pictures of different sculptures in the museum, such as the column crowns," said interviewee n 3, "and it is quite impossible to manage them, even though they have been instructed numerous times not to do so". 


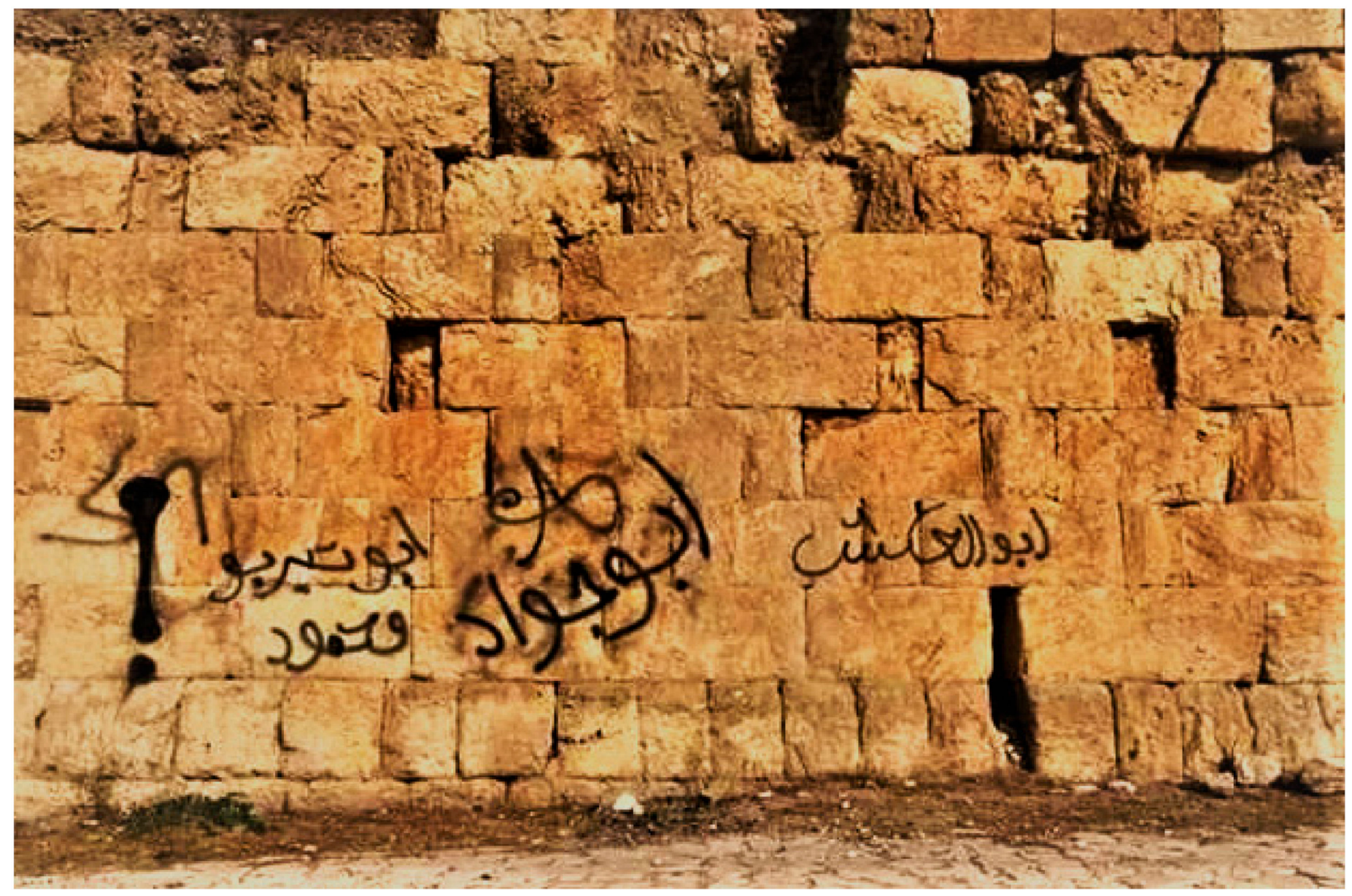

Figure 6. On-site graffiti. Source: Researchers.

Finally, certain archaeological relics have been removed purposefully or inadvertently. Local visitors have been spotted performing local dances at the site, which creates vibration and may have a detrimental influence on monuments and their stability. Furthermore, visitors may remove some archaeological relics, such as mosaic fragments, under a variety of circumstances. The presence of many recreational, cultural, and charitable activities and events, such as some bazaars at the parking, Jordan trail hikers' festival at the panoramic view (Figure 7), charitable events at the Western Theatre, cultural and social events at the visitor center, training and meetings at Al-Hara Al-Foga café, is another effect of the increase in visitor numbers.

Unfortunately, the residents are also to blame for other negative tourism-related impacts that, undeniably, affect the site's natural ecology. During the spring season, it was discovered that people of the local community had picked flowers to construct and sell yellow rose collars for visitors. The most active flower collectors are usually found around the parking lot and outside the venue. In the spring, children put this into reality by selling flowers to local tourists in order to make some money. During the fieldwork, it was observed that a number of youngsters and school students were present at the site early in the morning trying to sell yellow roses. 


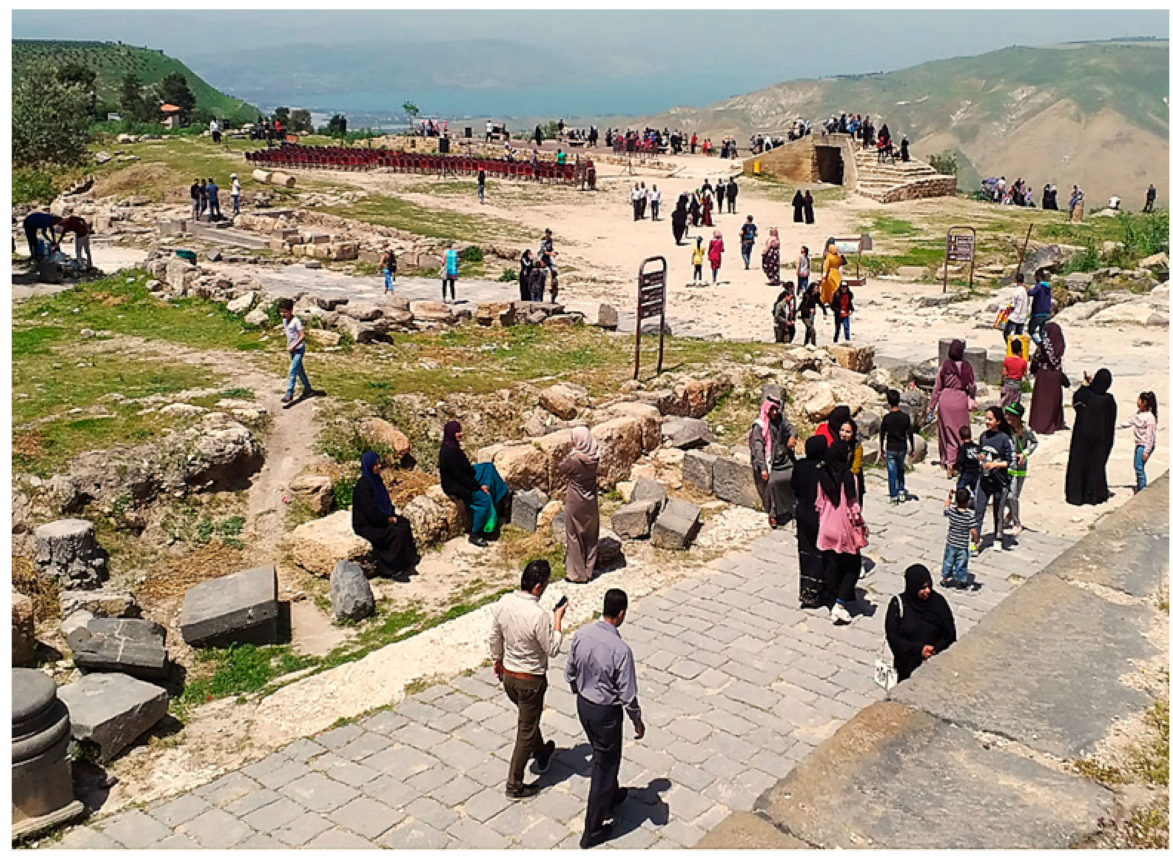

Figure 7. Welcoming festival of Jordan trail hikers at the site. Source: Researchers.

Furthermore, it was discovered that horseback riding is a popular pastime. Locals brought their horses to the site and provided brief rides to both locals and guests from other countries. Similarly, several of the respondents mentioned other harmful consequences of these horses that might injure tourists and negatively influence their experience at the site. One of the interviewees stated that "During the high season, the presence of horses is a major issue at the site. When these horses pass by, they wreak havoc, and many tourists are taken aback. Furthermore, certain accidents involving horse riders falling owing to a lack of professional training and sufficient safety measures have previously occurred". Climbing, strolling, and sitting atop monuments are all common behaviors among children and school pupils (Figure 8). These activities are said to be for a variety of reasons, and they may endanger the site's monuments as well as tourists.

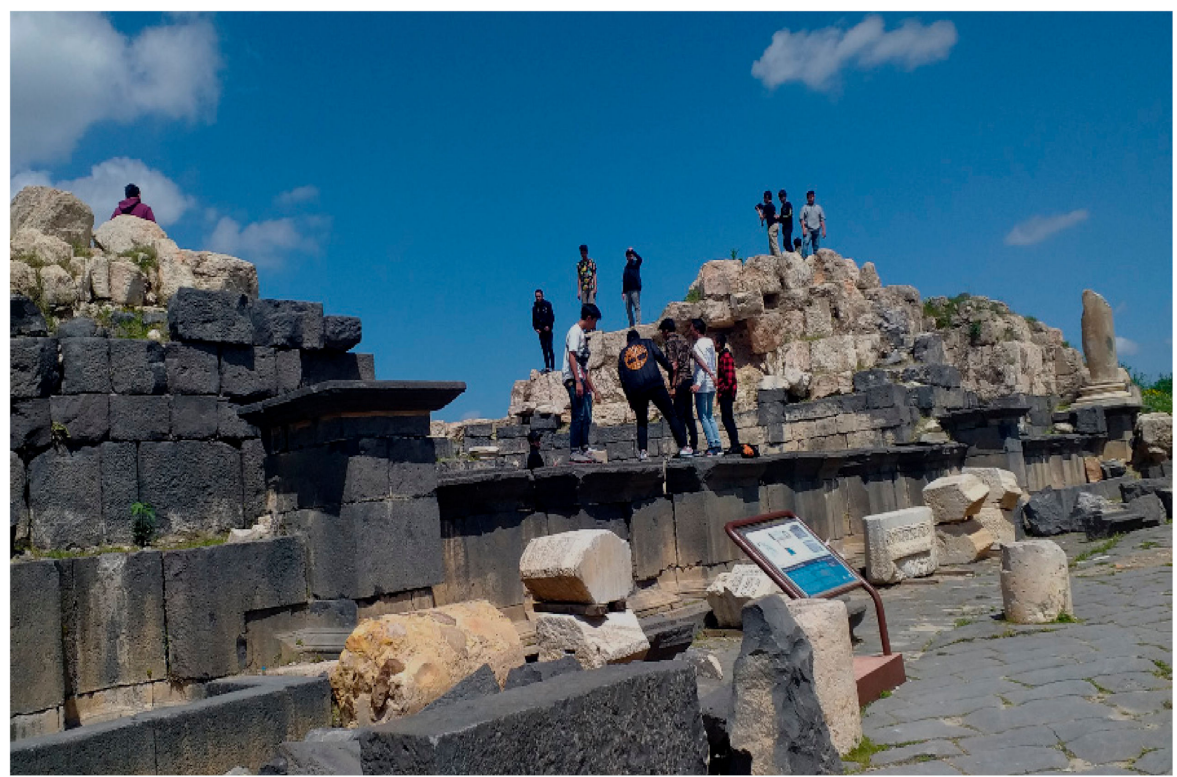

Figure 8. Improper behavior of school students at the site. Source: Researchers. 


\subsection{The Extent of Impacts}

In terms of the study's second goal, it is believed that negative tourism and visitor impacts are generally localized in limited zones and particular areas of the site in varying concentrations. For example, negative tourism impacts are more prevalent in areas where services and infrastructure have been introduced to the site, such as the Ottoman Village. At this location, problems of pollution, water turbidity, waste and visual pollution are highly observed. However, most of the negative visitor impacts are concentrated on the archaeological part (Table 3).

Table 3. Negative impacts typologies and their extent.

\begin{tabular}{|c|c|c|c|c|}
\hline \multicolumn{5}{|c|}{ Tourism Negative Impacts } \\
\hline Negative Impacts & Reason & Extent & Location & Notes \\
\hline $\begin{array}{l}\text { Vegetation and wildlife } \\
\text { degradation }\end{array}$ & $\begin{array}{c}\text { Excavation, } \\
\text { creation of new } \\
\text { purpose-built facilities, } \\
\text { conversion of original } \\
\text { facilities }\end{array}$ & $\begin{array}{l}\text { Very high at the } \\
\text { Ottoman village, } \\
\text { parking area } \\
\text { and the excavation } \\
\text { sector }\end{array}$ & $\begin{array}{c}\text { Police station, } \\
\text { restaurants, parking, } \\
\text { museum, visitor center, } \\
\text { cafés } \\
\text { Shops, colonnaded } \\
\text { street, panoramic view }\end{array}$ & $\begin{array}{l}\text { Very high in summer } \\
\text { and spring times }\end{array}$ \\
\hline Air and water pollution & $\begin{array}{l}\text { Vehicles, waste, } \\
\text { infrastructure }\end{array}$ & $\begin{array}{l}\text { Very high at parking } \\
\text { and Ottoman village } \\
\text { part }\end{array}$ & $\begin{array}{l}\text { Parking, tourist trails, } \\
\text { cafés and restaurants, } \\
\text { police station, museum, } \\
\text { visitor center, ticketing } \\
\text { office }\end{array}$ & $\begin{array}{l}\text { Very high in summer } \\
\text { and spring times }\end{array}$ \\
\hline Visual pollution & $\begin{array}{l}\text { Infrastructure and } \\
\text { services }\end{array}$ & $\begin{array}{l}\text { Very high at the } \\
\text { parking area, Ottoman } \\
\text { village }\end{array}$ & $\begin{array}{l}\text { Panoramic view, } \\
\text { visitor center }\end{array}$ & All the year \\
\hline $\begin{array}{l}\text { Accelerated } \\
\text { degradation }\end{array}$ & $\begin{array}{l}\text { Excavation works, } \\
\text { infrastructure }\end{array}$ & $\begin{array}{l}\text { Very high beside the } \\
\text { cardo, Ottoman village }\end{array}$ & $\begin{array}{l}\text { Cardo, the Ottoman } \\
\text { village, theatre }\end{array}$ & $\begin{array}{l}\text { Very high in summer } \\
\text { season }\end{array}$ \\
\hline Archaeological erosion & $\begin{array}{c}\text { Tourism activities and } \\
\text { services }\end{array}$ & $\begin{array}{l}\text { Very high at theatre, } \\
\text { churches, and } \\
\text { panoramic view }\end{array}$ & $\begin{array}{l}\text { Theatre, columns, } \\
\text { churches, nymphaeum, } \\
\text { tombs }\end{array}$ & All the year \\
\hline \multicolumn{5}{|c|}{ Visitors negative impacts } \\
\hline $\begin{array}{l}\text { Vegetation and wildlife } \\
\text { degradation }\end{array}$ & $\begin{array}{c}\text { Movement and } \\
\text { circulation of visitors, } \\
\text { picking wildflowers by } \\
\text { locals }\end{array}$ & $\begin{array}{l}\text { High along the visited } \\
\text { areas and the visitor } \\
\text { trails, parking and } \\
\text { outside around }\end{array}$ & $\begin{array}{l}\text { Around the parking } \\
\text { area, museum, } \\
\text { archaeological sector, } \\
\text { panoramic view }\end{array}$ & $\begin{array}{l}\text { Increased during } \\
\text { school trips season }\end{array}$ \\
\hline Littering & Local visitors & $\begin{array}{l}\text { High at the parking, } \\
\text { theatre, between } \\
\text { historical houses, cardo, } \\
\text { panoramic view }\end{array}$ & $\begin{array}{l}\text { Historical houses, } \\
\text { theatre, parking }\end{array}$ & Very high in springtime \\
\hline Graffiti & $\begin{array}{l}\text { Visitors signing their } \\
\text { names and date of their } \\
\text { visit }\end{array}$ & $\begin{array}{l}\text { High at the } \\
\text { archaeological sector }\end{array}$ & $\begin{array}{l}\text { Theatre, parking, } \\
\text { columns, stairs, signs }\end{array}$ & $\begin{array}{c}\text { Different materials } \\
\text { were used for graffiti } \\
\text { like paint spray and } \\
\text { chalk }\end{array}$ \\
\hline Vandalism & Visitors & $\begin{array}{c}\text { High at the } \\
\text { archaeological area and } \\
\text { the ottoman village } \\
\text { parts }\end{array}$ & $\begin{array}{l}\text { Columns, signs, theatre, } \\
\text { parking }\end{array}$ & $\begin{array}{l}\text { purposefully or } \\
\text { inadvertently }\end{array}$ \\
\hline Noise & Visitors-locals & $\begin{array}{c}\text { High at the } \\
\text { archaeological sector }\end{array}$ & $\begin{array}{c}\text { Theatre, parking, } \\
\text { visitor center, museum, } \\
\text { panoramic view, } \\
\text { churches, restaurants }\end{array}$ & $\begin{array}{l}\text { Very high in springtime } \\
\text { and summer }\end{array}$ \\
\hline
\end{tabular}


Table 3. Cont.

\begin{tabular}{ccccc}
\hline Negative Impacts & Reason & Tourism Negative Impacts & Location & Notes \\
\hline Pollution & $\begin{array}{c}\text { Visitors and staff } \\
\text { vehicles }\end{array}$ & $\begin{array}{c}\text { High at the Ottoman } \\
\text { and archaeological } \\
\text { sector }\end{array}$ & $\begin{array}{c}\text { Restaurant, parking, } \\
\text { panoramic view }\end{array}$ & $\begin{array}{c}\text { Very high during } \\
\text { working and operation } \\
\text { hours }\end{array}$ \\
\hline Crowds and congestion & Visitors & $\begin{array}{c}\text { Very high at the } \\
\text { archaeological sector } \\
\text { and the Ottoman } \\
\text { village }\end{array}$ & $\begin{array}{c}\text { Parking, theatre, } \\
\text { panoramic view, } \\
\text { churches, restaurant, } \\
\text { museum }\end{array}$ & $\begin{array}{c}\text { Very high in springtime } \\
\text { and during school } \\
\text { students trips }\end{array}$ \\
\hline
\end{tabular}

Litter was found in several locations in the parking lot between the historic residences and monuments on the site. Traffic, congestion, and overcrowding are more common in the parking lot and along the route that connects the parking lot to the most popular monuments and attractions on the site, such as the western theater, the panoramic view, and the museum. Graffiti appears to be common in the archaeological site. The most frequented areas surrounding the theatre, the panoramic view, and the museum have the most vegetation damage. The majority of the negative visitor impacts are focused on a narrow area of the site between the parking lot, the western theatre, the panoramic view, and the homes that have been altered to serve contemporary activities like the museum, café, and police station. Outside of this zone, albeit to a lesser extent, impacts can be seen, notably along the main colonnaded street (Figure 9).

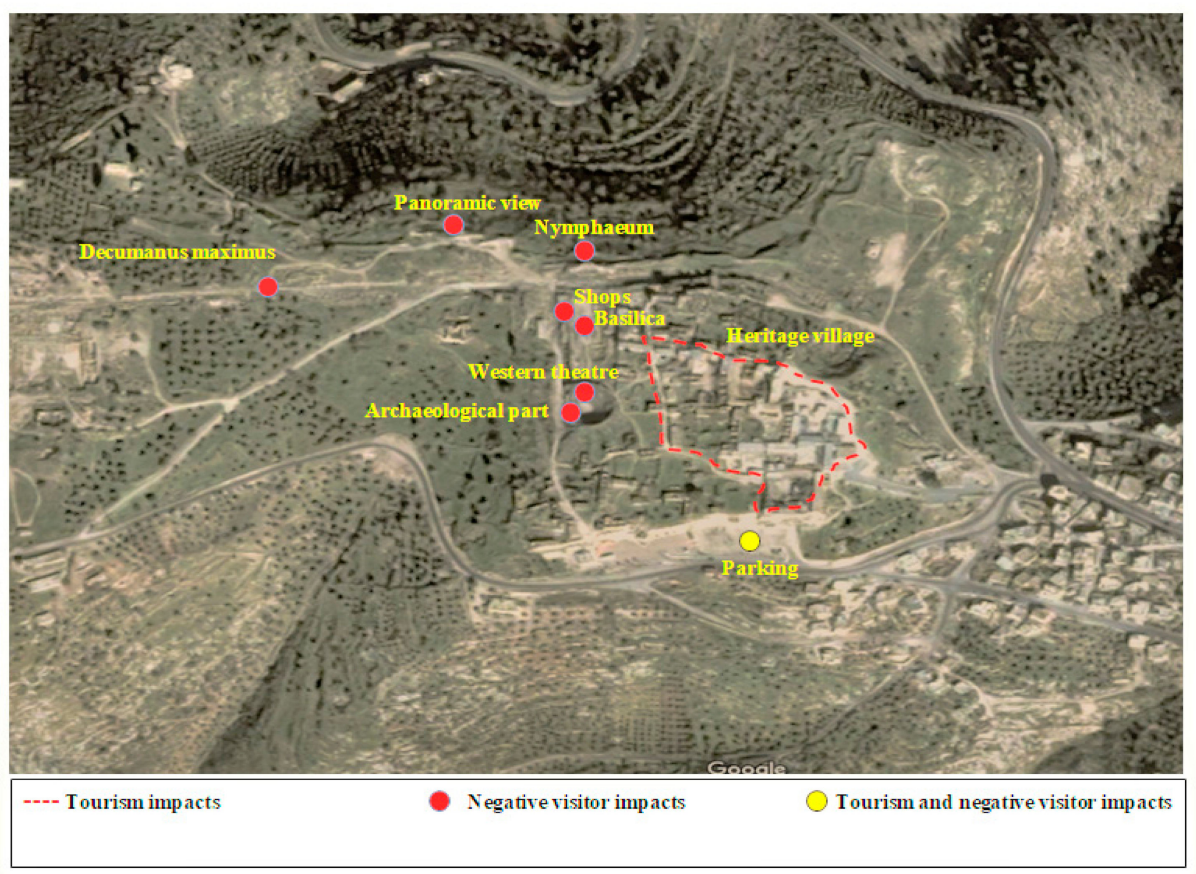

Figure 9. Spatial distribution of tourism and visitor negative impacts. Source: Modified by researchers based on an image from Google Maps, 2020.

\section{Discussion}

Both tourists and tourism-related services affect the natural ecology. Visitors disrupt eco-systems by degrading vegetation, killing species intentionally or accidentally. Air and water quality are affected by pollution, while archeological monuments, tourism services and facilities, and historical structures are affected by vandalism, graffiti, and erosion. The area is filled with unorganized services and odd businesses. The general nature of the site is threatened as a result of the spread of tourism development features. The negative 
consequences are not limited to the evident physical impacts inside the site's boundaries. The impact goes beyond the limits of the place and beyond the immediate and visible impacts. The repercussions of these acts are real since local leaders choose to expose the site to the public. Since then, excavation activities and tourism development services have been carried out at the site in order to transform it into a tourist attraction. This forced the displacement of locals, which might be considered the site's first negative impact of increased tourists. Land use patterns altered as a result of the displacement of the local population, leaving some historic dwellings abandoned and even deteriorating. Some have been demolished, while others have been relegated to the margins. The deterioration process mostly affects the walls and creative interior components. In addition, their original function has been frozen, while others are being used for non-adaptive reuse. Excavation has aided in the physical rearrangement of the site, but tourist-related negative activities have harmed the natural ecology. Historic and physical continuity, as well as heritage values, are at risk. On a broader scale, the tourist experience is threatened, and concerns about tourism and cultural preservation are in jeopardy.

The local community's conception of the archaeological site and medieval town of Umm Qais as a place of ancestors has dominated the conversation. However, since the 1980s, when the local community was displaced, this has been undervalued. The connected historical backdrop, the archaeological sector, the cultural tissue, and the natural landscape all contribute to Umm Qais' cultural, historical, and architectural magnificence. Despite this, the site is distinguished by an open, unbroken cultural and natural landscape.

The present pattern and intensity of impacts have been influenced by site management methods, tourist planning, seasonality, and visitor behavior. Since the 1960s, site management has prioritized three site-based products: archaeological monuments, historical structures, and the natural panorama view. The site administration recognizes that a few services and amenities are necessary to provide a pleasant visitor experience; they focused their efforts on excavation, tourism development, tourism services, and visitor experience in a small area of the site. As a result, site management is actively involved in the creation of a small multi-purpose area for services, events, activities, and tourist circulation. Despite the fact that the site has a lot of space, it was determined that all of the activities are concentrated in a small area. The theatre, museum, tourism trails, visitor center, and parking are all crammed into a small space. This area attracts the greatest number of national and international visitors (Figure 10).

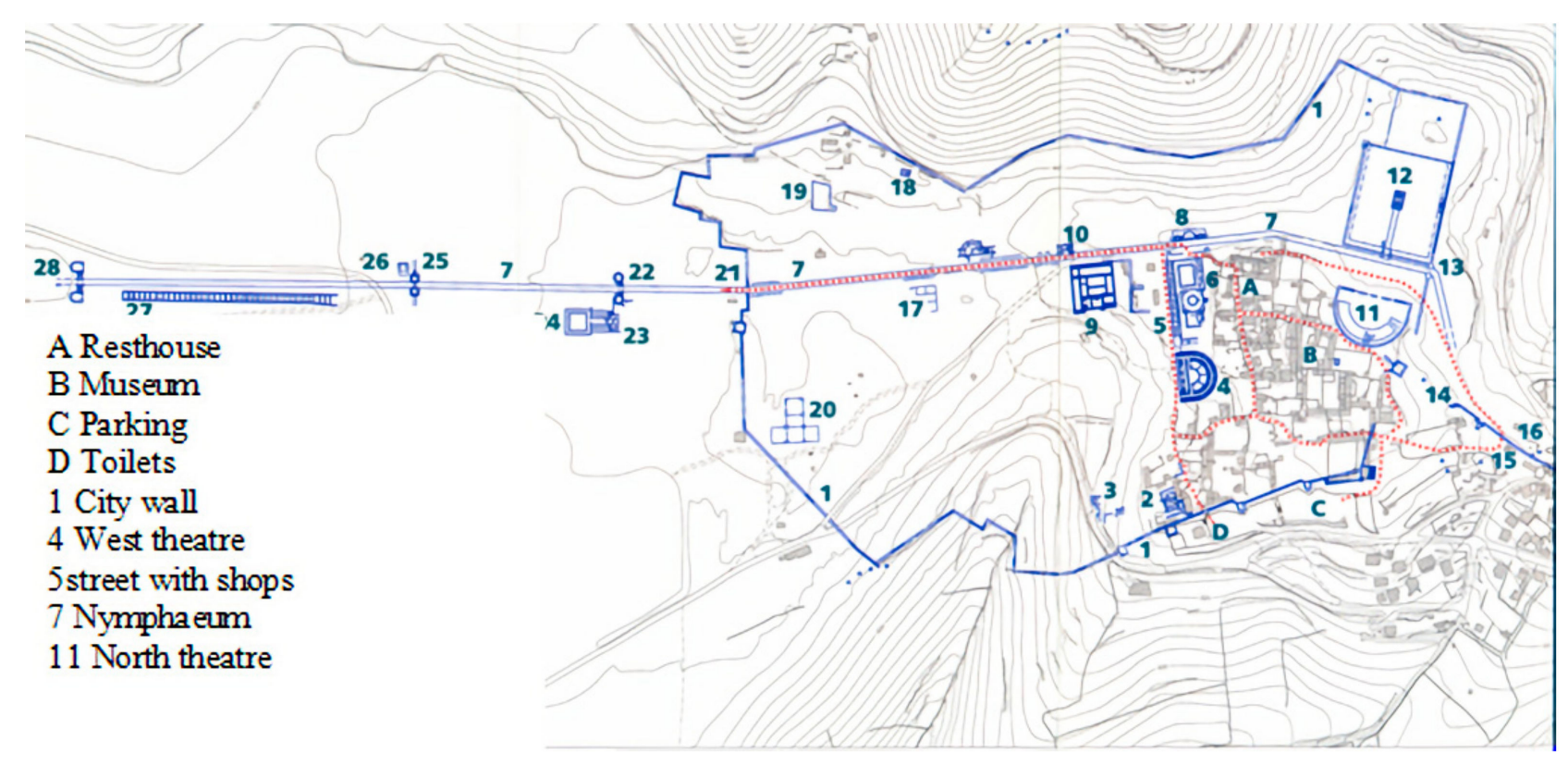

Figure 10. Site plan. Source: researchers based on Google Images 2020. 
Seasonality and tourist behavior have exacerbated the problem. Seasonality is responsible for amplifying unfavorable impacts at particular periods of the year, as shown in $[49,50]$. Visitor behavior has exacerbated unfavorable trends in many locations, and it is thought that locals are to blame for the bulk of vandalism and graffiti in a given area. Tourism activity is most visible during the national tourism seasons of spring (March, April, and May) and autumn (September, October, and November), as well as during the Christmas holiday season, when Umm Qais sees an influx of visitors. As a result, visitor utilization is higher during these times than during other times of the year. Tourist services are in more demand during peak seasons than during low seasons, and tourism operators must meet these needs. When compared to other daily hours, the morning and afternoon are the periods of the day with the largest number of visits. However, there are no substantial visitor impacts during the low seasons. The consequences are more concentrated inside this tiny archaeological region, which is supported by the fact that the bulk of visitors' activity, mobility, and circulation are restricted to this area, whereas visitation to the Ottoman residential area is restricted.

Site-specific components, such as those that are reliant on site management and planning, exist. It's conceivable that the site's financial and personnel resources are insufficient. A lack of financial and human competency resulted in the absence of a general management plan, as well as sub-visitor and interpretation plans. The tourist and historical sectors are not separated from the commercial and administrative areas. The current planning has developed a single tourism activity area in addition to the commercial and administrative sectors. Visitors' movement and circulation are not controlled by the site's visitor management techniques. In addition, the site lacks a thorough interpretive teaching method for fostering enthusiasm. The visitor control system, on the other hand, is ineffective and relies on ten guards.

Throughout the visit, visitors' behavior, awareness, and attitude are all factors to consider. Some of the repercussions have been linked to certain types of visitors, such as trash and graffiti, which are mostly associated with local, anecdotally young visitors to the site. Visitors are affected by demographic, socioeconomic, quantity, and visit patterns, among other factors. Visit patterns are expressed and restricted to particular zones with higher visitor numbers and activity inside the site.

There is a scarcity of effective tourism and visitor management strategies, according to the present study's results. At the time, there were no licensed tour guides on hand. Furthermore, the majority of the site's management plans were centered on the trash's impact. This manifested itself in the placement of many trash bins of various shapes, materials, and colors across the site, as well as an increase in the number of janitors during peak season and cleaning programs that, unfortunately, had the opposite impact on the site. Despite all of the efforts made to manage historic assets at the site and at the national level, it is plausible to deduce that the present management framework is the major cause of this situation, which conforms to the conclusions of some local studies such as $[16,32,51,52]$. This might entail, among other things, a lack of written management plans, conservation plans, interpretative plans, and visitor management plans. Furthermore, there are no specific site protection guidelines, no signs alerting visitors of fragile, vulnerable structures or zones, and a lack of harmonization among directional and information signs. It was obvious that their placements had not been picked with care. However, there are 11 signs installed at the site along the trail, including information, directions, promotion and interpretive signs. The trails were not well marked, and it was difficult to understand the pattern of the visit. As a result, visitors were occasionally perplexed, and it was difficult to understand the layout of the visit, where the ticketing office was located, and the difficulties in locating other services (Figure 11).

Existing heritage and tourism management literature has provided a breadth of knowledge on heritage site management and protection, as well as the management planning process. However, there is no agreement concerning unique best practices for site protection and management. Therefore, while there is no unique management planning 
system, different scholars argue that opening heritage sites for tourists should commence with planning. The planning process provides frameworks for overall management of the site based on a mix of the needs of the site, the visitors and the management process itself. This study reaffirms $[7,16,22,34,36,39,40,43]$ findings and arguments. These studies revealed different impacts due to different factors associated with tourism development. These studies suggest that management concerns are related to lack of funding and expertise, in addition to weak planning. In this regard, it should be considered that a large number of tourists concentrated only in a few open areas of the site causes more damage than leaving people to disperse throughout the site [22]. Finally, the findings of the study reinforce the importance of heritage management at archaeological sites and their analysis frameworks.

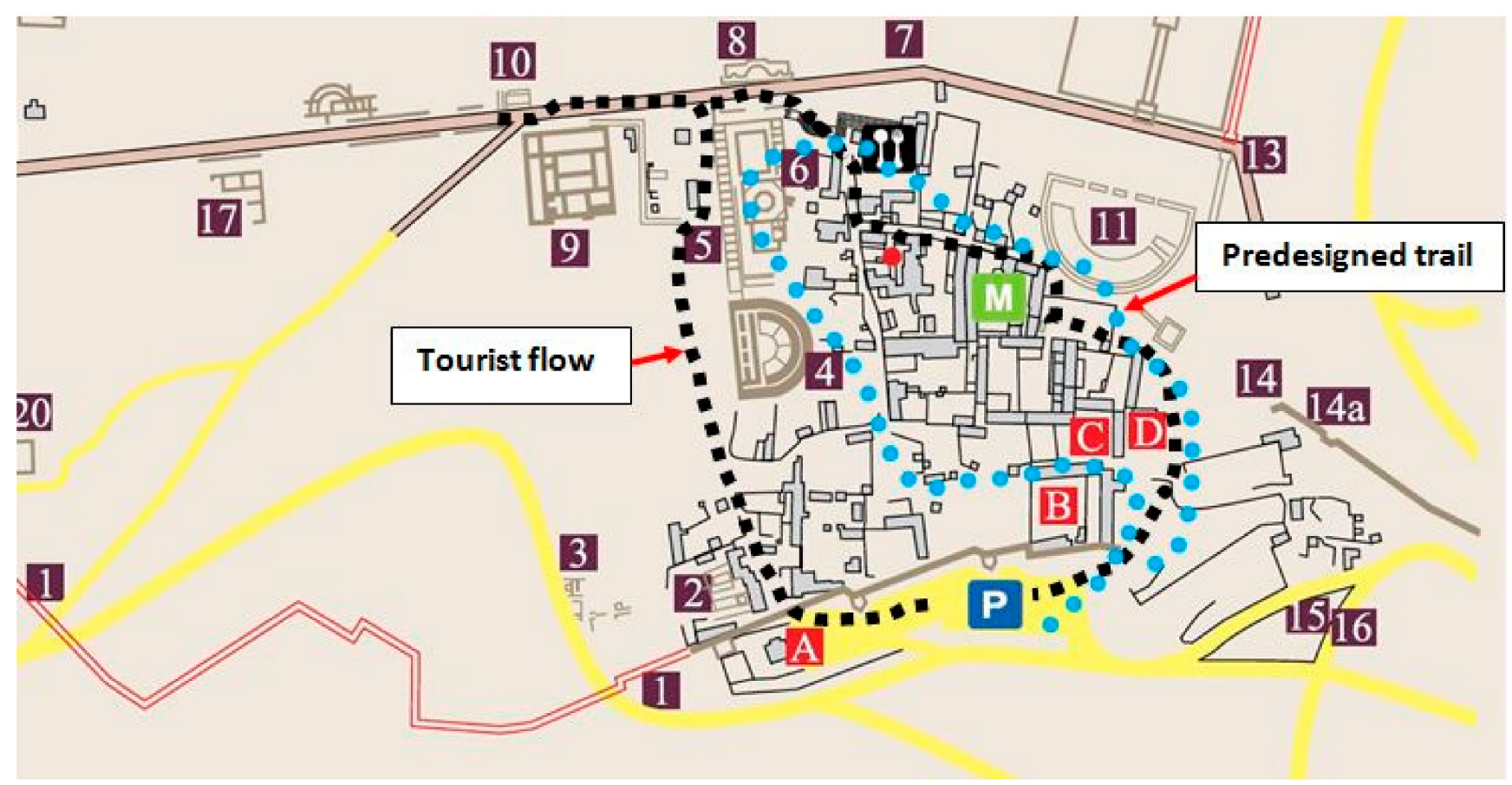

Figure 11. Predesigned trail and tourist flow. Source: Modified by researchers based on an image from the Jordan Tourism board.

\section{Conclusions}

The site's value, although not generally defined, is threatened, according to this research. The site has been managed and developed with a focus on tourist growth rather than the preservation of the monument's integrity. Protecting archaeological monuments that have been created as a result of tourism is a tough and time-consuming task. Hence, it is recommended that the governing bodies of the site take necessary actions. Firstly, the most essential proposal for tourism-related services and facilities is to relocate them outside of the present archaeological site's borders. They may be located in Umm Qais' contemporary village, which would decrease negative impacts on the site and increase tourism activities in the new area, implying that visitors' stays or tours would be longer and more involved. Secondly, is to lengthen the tourist seasons to prevent temporal disadvantages focused on the spring season by enhancing the site's attractions, particularly those beyond the little developed present zones stretching between the theatre and the panoramic view. This might assist in minimizing visitor densities in terms of time and space. Thirdly, reorganize and expand the site's present undeveloped pathways, reduce crowding, and maintain a balance between frequented zones. Fourth, local stakeholders must be trained, a site-based system must be established to collect full data on the site's visitors, and visitor management measures such as site guards, visiting hours, and zoning 
must be implemented. Furthermore, guided tours can be used to get access to the site, and the maximum number of participants can be set as part of a carrying capacity plan [52].

The interpretation could be better developed to educate visitors about the importance of the site and the need for its protection. In this regard, training of site employees is necessary to undertake a comprehensive interpretation plan based on the full usage of interpretive methods, such as developed signage, visitor centers, brochures, hi-tech interpretive media, and well-trained local guides who may be used jointly to educate visitors and local stakeholders to reduce negative impacts.

Finally, the formation of a single organization dedicated to site management and tourist development is the suggestion for overall site management and tourism development. This entity consists of a site manager and a team of archaeologists, conservators, tourist developers, archivists, researchers' interpreters, and others who are familiar with site management planning guidelines that strike a balance between the needs of site conservation and tourism development. This organization will require financial resources as well as new legal frameworks that reflect a wide range of factors, such as site value, site needs, tourist development measures, visitor experience, and local community engagement. These measures cannot be applied without sufficient financial resources. Financial support could be provided by increasing the budget by cutting a percentage of site-based entry charges.

Author Contributions: Conceptualization, A.A. and R.A.; methodology, R.A.; formal analysis, R.A.; investigation, R.A. writing-original draft preparation, R.A.; writing-review and editing, A.A.; supervision, A.A. All authors have read and agreed to the published version of the manuscript.

Funding: This research received no external funding.

Institutional Review Board Statement: Not applicable.

Informed Consent Statement: Not applicable.

Data Availability Statement: Not applicable.

Acknowledgments: The authors would like to express their gratitude to the staff of the site of Umm Qais for supporting the fieldwork visits.

Conflicts of Interest: The authors declare no conflict of interest.

\section{References}

1. Abu-Allaban, M.; El-Khalili, M.M. Antiquity impact of air pollution at Gadara, Jordan. Mediterr. Archaeol. Archaeom. 2014, 14, 191-199.

2. Zoubi, N.S. Restructuring the Archaeological Museum of Umm Qais. Master's Thesis, Yarmouk University, Irbid, Jordan, 2012.

3. MoTA. Monthly Number of Visitors to Umm Qais by Nationality. Statistical Newsletter. 2020. Available online: http://www. mota.gov.jo/Contents / StatisticsAr.aspx (accessed on 7 June 2021).

4. Demas, M.; Agnew, N.; Fan, J.; Maekawa, S. Strategies for Sustainable Tourism at the Mogao Grottoes of Dunhuang, China; Springer International Publishing: Cham, Switzerland, 2015.

5. Mason, P. Visitor management in protected areas: From 'hard'to 'soft'approaches? Curr. Issues Tour. 2005, 8, 181-194. [CrossRef]

6. Roberts, T. Interpretation design: An integrative, interdisciplinary practice. Mus. Soc. 2014, 12, $191-209$.

7. Enseñat-Soberanis, F.; Frausto-Martínez, O.; Gándara-Vázquez, M. A visitor flow management process for touristified archaeological sites. J. Herit. Tour. 2019, 14, 340-357. [CrossRef]

8. Albrecht, J.N. Introduction to visitor management in tourism destinations. In Visitor Management in Tourism Destination; Albrecht, J.N., Ed.; CABI Publishing: Wallingford, UK, 2017; pp. 3-8.

9. Al-Bashaireh, K. Provenance of marbles from the octagonal building at Gadara "Umm-Qais", Northern Jordan. J. Cult. Herit. 2011, 12, 317-322. [CrossRef]

10. Alobiedat, A.A. The Impacts of Heritage Tourism on Gadara, Northern Jordan; Arkansas State University: Jonesboro, AR, USA, 2014.

11. Mustafa, M.; Hijjawi, D.; Balaawi, F. Tourism impacts in the site of Umm Qais: An overview. J. Tour. Hosp. Manag. 2019, 6, 140-148. [CrossRef]

12. Timothy, D.J. Cultural Heritage and Tourism; Channel View Publications: Bristol, UK, 2021.

13. Light, D. Heritage and tourism. In The Palgrave Handbook of Contemporary Heritage Research; Palgrave Macmillan: London, UK, 2015; pp. 144-158.

14. Fonseca, F.P.; Ramos, R.A. Heritage tourism in peripheral areas: Development strategies and constraints. Tour. Geogr. 2012, 14, 467-493. [CrossRef] 
15. Prentice, R. Tourism and Heritage Attractions; Routledge: London, UK, 1993.

16. Ababneh, A. Heritage management and interpretation: Challenges to heritage site-based values, reflections from the heritage site of Umm Qais, Jordan. Archaeologies 2016, 12, 38-72. [CrossRef]

17. Orbasli, A. Tourists in Historic Towns: Urban Conservation and Heritage Management; Taylor \& Francis: Abingdon-on-Thames, UK, 2002.

18. Jokilehto, J. World heritage: Observations on decisions related to cultural heritage. J. Cult. Herit. Manag. Sustain. Dev. 2011, 1, 61-74. [CrossRef]

19. Boswell, R. Challenges to Identifying and Managing Intangible Cultural Heritage in Mauritius, Zanzibar and Seychelles; African Books Collective: Oxford, UK, 2008.

20. Yuan, C.; He, Y.; Feng, Y.; Wang, P. Fire hazards in heritage villages: A case study on Dangiia Village in China. Int. J. Disaster Risk Reduct. 2018, 28, 748-757. [CrossRef]

21. Fenger-Nielsen, R.; Hollesen, J.; Matthiesen, H.; Andersen, E.A.S.; Westergaard-Nielsen, A.; Harmsen, H.; Elberling, B. Footprints from the past: The influence of past human activities on vegetation and soil across five archaeological sites in Greenland. Sci. Total Environ. 2019, 654, 895-905. [CrossRef]

22. Palumbo, G. Threats and challenges to the archaeological heritage in the Mediterranean. In Management Planning for Archaeological Sites: An International Workshop Organized by the Getty Conservation Institute and Loyola Marymount University, 19-22 May 2000, Corinth, Greece; Teutonico, J., Teutonico, J.M., Palumbo, G., Eds.; Getty Publications: Los Angeles, CA, USA, 2000 ; pp. 3-13.

23. Shackley, M. Visitor Management; Routledge: London, UK, 2009.

24. Grove, L.; Thomas, S. Heritage Crime: Progress, Prospects and Prevention; Springer: Berlin, Germany, 2014.

25. Tandon, A. Endangered Heritage: Emergency Evacuation of Heritage Collections, ICCROM. UNESCO Publishing. 2016. Available online: https:/ / www.iccrom.org/sites/default/files/2017-12/endangered-heritage_interactive.pdf (accessed on 7 July 2018).

26. Shackley, M. Conclusions-Visitor management at Cultural World Heritage Sites. In Visitor Management; Routledge: London, UK, 2011; pp. 194-205.

27. Tosun, C. Challenges of sustainable tourism development in the developing world: The case of Turkey. Tour. Manag. 2001, 22, 289-303. [CrossRef]

28. Zhou, L.Q.; Huang, Z.H. Sustainable development of rural tourism in China: Challenges and policies. Econ. Geogr. $2004,4,035$.

29. D'Antonio, A.; Monz, C.; Newman, P.; Lawson, S.; Taff, D. Enhancing the utility of visitor impact assessment in parks and protected areas: A combined social-ecological approach. J. Environ. Manag. 2013, 124, 72-81. [CrossRef]

30. Shen, C. Evaluating Values of World Heritage Sites and Cultural Tourism in China. In Heritage Values in Contemporary Society; Smith, G.S., Messenger, P.M., Soderland, H.A., Eds.; Routledge: London, UK, 2017; pp. 255-266.

31. Stevčić, Č.; Pérez-Miguel, M.; Drake, P.; Tovar-Sánchez, A.; Cuesta, J.A. Macroinvertebrate communities on rocky shores: Impact due to human visitors. Estuar. Coast. Shelf Sci. 2018, 211, 127-136. [CrossRef]

32. Al-Saad, S. The Conflicts between Sustainable Tourism and Urban Development in the Jerash Archaeological Site (Gerasa), Jordan. Ph.D. Thesis, Catholic University of Eichstätt-Ingolstadt, Eichstätt, Germany, 2014.

33. Mustafa, M.H.; Tayeh, S.N. The impacts of tourism development on the archaeological site of Petra and local communities in surrounding villages. Asian Soc. Sci. 2011, 7, 88. [CrossRef]

34. Comer, D.C. Tourism and Archaeological Heritage Management at Petra; Springer: Berlin, Germany, 2012.

35. De Groot, R.S.; van de Berg, A.; Amelung, B. Cultural and amenity services. In Ecosystems and Human Well-Being: Current State and Trends; Findings of the Condition and Trends Working Group; University of Pretoria: Pretoria, South Africa, 2005; Volume 1, p. 455.

36. Mason, P. Tourism Impacts, Planning and Management; Routledge: London, UK, 2020.

37. ICCROM. A Guide to Risk Management of Cultural Heritage; ICCROM: Rome, Italy, 2016.

38. Tunbridge, J.E.; Ashworth, G.J. Dissonant Heritage: The Management of the Past as a Resource in Conflict; John Wiley \& Sons: Chichester, UK, 1996.

39. Ababneh, A. Managing heritage tourism in the Decapolis sites of Jordan: Planning opportunities and challenges. Tour. Cult. Commun. 2015, 15, 141-156. [CrossRef]

40. Pedersen, A. Managing Tourism at World Heritage Sites: A Practical Manual for World Heritage Site Managers; UNESCO World Heritage Center: Paris, France, 2002.

41. El-Khalili, M.M. Revival of cultural heritage: The case study of the Ottoman Village in Umm Qais. Jordan J. Hist. Archaeol. 2014, 8, 118-135.

42. Pierson, W.A. Spatial Assessment of Urban Growth in Cities of the Decapolis; and the Implications for Modern Cities. Ph.D. Thesis, University of Arkansas, Fayetteville, AR, USA, 2021.

43. Starman, A.B. The case study as a type of qualitative research. J. Contemp. Educ. Stud. Sodob. Pedagog. 2013, 64, $28-43$.

44. Hoepfl, M.C. Choosing qualitative research: A primer for technology education researchers. J. Technol. Educ. 1997, 9, 47-63. [CrossRef]

45. Shank, G.; Villella, O. Building on new foundations: Core principles and new directions for qualitative research. J. Educ. Res. 2004, 98, 46-55. [CrossRef]

46. Chin, C.L.; Moore, S.A.; Wallington, T.J.; Dowling, R.K. Ecotourism in Bako National Park, Borneo: Visitors' perspectives on environmental impacts and their management. J. Sustain. Tour. 2000, 8, 20-35. [CrossRef] 
47. Drdácký, M.; Drdácký, T.; Creighton, T. Impacts and Risks in Relation to Individual Historic Objects. Pro-Active Management of the Impact of Cultural Tourism upon Urban Resources and Economies; PICTURE: European Commission Sixth Framework Programme of Research; European Commission: Brussels, Belgium, 2005.

48. Garrod, B.; Fyall, A.; Leask, A. Managing visitor impacts at visitor attractions: An international assessment. Curr. Issues Tour. 2006, 9, 125-151. [CrossRef]

49. Pour, F.A.; Shokri, M.R.; Abtahi, B. Visitor impact on rocky shore communities of Qeshm Island, the Persian Gulf, Iran. Environ. Monit. Assess 2013, 185, 1859-1871. [CrossRef]

50. Ćorluka, G. Tourism seasonality: An overview. J. Bus. Paradig. 2019, 4, 21-43.

51. Al-Saad, S.A. The Impact of Modern Urbanization on the Cultural Landscape of Jerash Archaeological Site. Master's Thesis, Yarmouk University, Irbid, Jordan, 2008.

52. Ababneh, A.; Darabseh, F.; White, R. Assessment of visitor Management at the Archaeological Site of umm Qais: Condition and problems. Conserv. Manag. Archaeol. Sites 2014, 16, 322-340. [CrossRef] 